\title{
Immunity response of mice infected with laser irradiated protoscoleces of Echinococcus granulosus
}

\author{
Zeena Dhubyan Mohammed Zaki ${ }^{1 *}$, Asmaa Abdulaziz Ali ${ }^{2}$ \\ ${ }^{1 *}$ Department of Dentistry, Al-Noor University College, Bartylla - Iraq \\ ${ }^{2}$ Department of Biology, Education College for Pure Sciences, University of Mosul, Mosul, Iraq \\ E-mail: ${ }^{1^{*}}$ zeena.dabian@alnoor.edu.iq, ${ }^{2}$ dr.asmaa abdulaziz@ uomosul.edu.iq
}

(Received April 24, 2021; Accepted June 21, 2021; Available online August 28, 2021)

DOI: 10.33899/edusj.2000.168653, (c) 2021, College of Education for Pure Science, University of Mosul.

This is an open access article under the CC BY 4.0 license (http://creativecommons.org/licenses/by/4.0/).

\begin{abstract}
The present study investigated the effect of the Neodymium- Doped Yttrium Aluminum Garnet (Nd: Y3AL5G12) Laser eradiation $1000 \mathrm{mw}$, against infection with secondary hydatid disease in BALB/c mice by inoculating the animals with protoscoleces of Echinococcus granulosus exposed to laser irradiation, for various periods $40,60,120$ and 240 minutes, with viability of 70\%,57\%,50\% and 40\%, respectively, contrasted to the control set (mice inoculated with unexposed protoscoleces) along three months, depending on the evaluation of the total count of WBCs and assessment of acquired cell- mediated immunity, demonstrated by delayed type hypersensitivity test (DTH).

The results showed considerable increase $(\mathrm{p}<0.01)$ in the total WBCs counting, in mice injected with irradiated protoscoleces, up to $13962 \mathrm{cell} / \mathrm{cm}^{3}$, in comparison to the control group $5420 \mathrm{cell} / \mathrm{cm}^{3}$, after 120 minutes, two months post infection. Moreover, there was considerable excess $(\mathrm{p}<0.01)$ in the foot pad thickness in treated mice, $2.94 \mathrm{~mm}$ after 120 minute (24hour post antigen injection), two months post infection, $2.86 \mathrm{~mm}$ after 120 minutes (24 hours post antigen injection), 1 month post infection and 2.64 $\mathrm{mm}, 120$ minutes ( 24 hours post antigen injection), three months post infection, compared with the control group $1.18 \mathrm{~mm}, 1.80 \mathrm{~mm}$ and $1.72 \mathrm{~mm}$, respectively.

Results revealed that irradiation of Echinococcus granulosus protoscoleces with laser had a significant influence on the production of WBCs and stimulation of delayed-type hypersensitivity reaction in mice.
\end{abstract}

Keywords: Hydatid disease, Echinococcus granulosus, laser eradiation

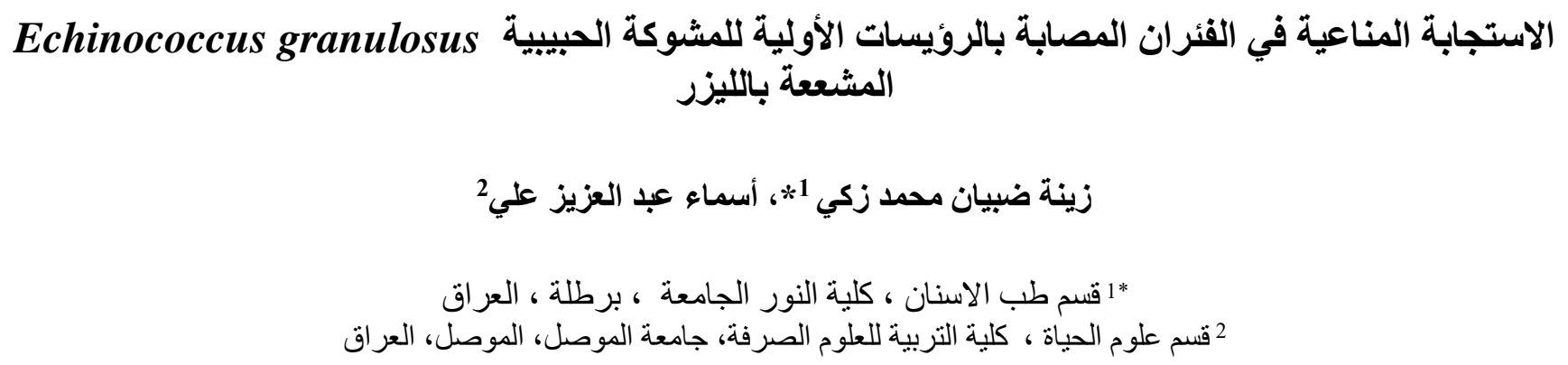




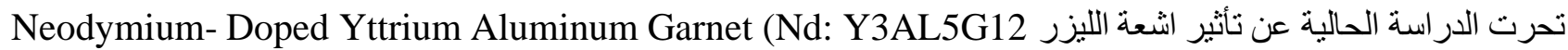

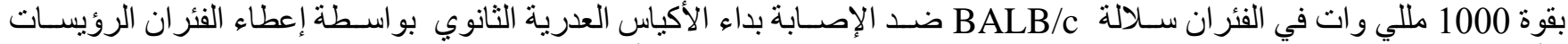

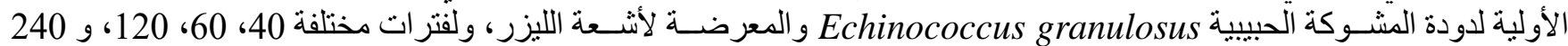

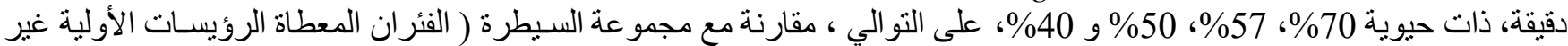

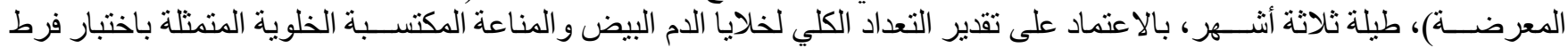
الحساسية المتأخر ( DTH ).

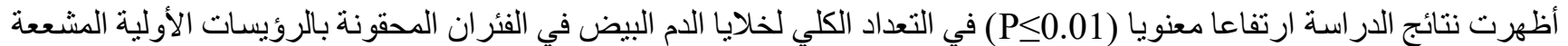

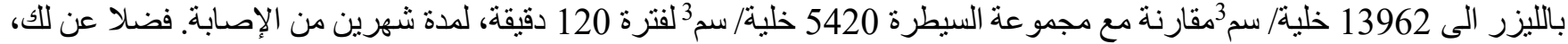

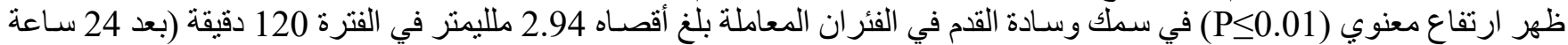

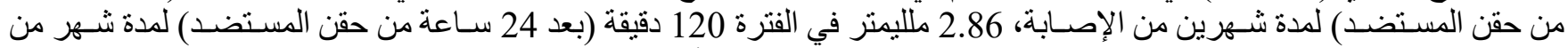

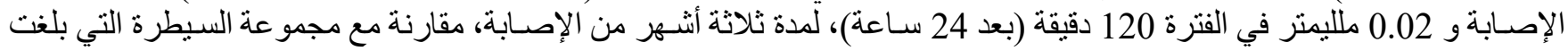

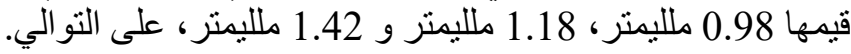

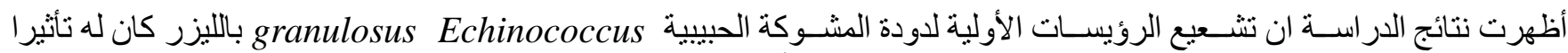
معنويا في تكاثر خلايا الدم البيض وتحفيز تلفيز تفاعل فرط الحساسية المتأخر في الفئران.

الكلمات المفتاحية: داء الاكياس العدرية ، المشوكة الحبيية Echinococcus granulosus ، اشعة الليزر

\section{Introduction}

E. granulosus is the causative agent of cystic echinococcosis in human beings and other animal hosts. This disease is a zoonosis that usually infects domestic animals and livestock and creates a general health and economic problem $(1,2)$. The disease spreads in the Middle East, Germany, Central Asia, Spain, Australia, and regions central and southern regions of the former Soviet Union, northern and southern regions of China, East Africa and the semi-desert regions of Africa and South America (3). The hydatid cyst grows slowly and can be located in different places in the human body, the infection may be asymptomatic, especially in its early stages, and there are many unregistered cases in the affected areas (4). Diagnosis of hydatid disease is based on immunoassay methods including indirect hemagglutination, indirect immunofluoresence, counter-current immunoelectrophoresis, radioimmunoassay, and enzymelinked immunosorbent assay (ELISA). (5-7). In addition to imaging techniques ultrasound, Computed Tomography $(\mathrm{CT})$, Magnetic resonance Imaging and $\mathrm{x}$ ray $(8,9)$.

The percentage of infection distribution in the organs varies according to the host and the methods of transmission of the parasite, the infection develops mainly in humans in the liver $70 \%$, lungs $20 \%$, and to a lesser extent in the heart, brain, bones, spleen, kidneys, central nervous system and adrenergic gland (4). There are many ways to treat cystic echinococcosis (8). Recently, there are three options for treating hydatid cysts in different organs: surgery, puncture-aspiration-injection, and medical treatment. $(6,10)$, for the medical treatment, Albendazole is treatment of choice, rather than Mebendazole or Benzimidazole Carbamates (6).

Researchers investigated better therapeutic non-invasive alternatives, as safe killers for the protoscoleces and stimulative of the immune system, including electromagnetic radiation techniques, ultrasound, ultraviolet, Gamma ray, laser (11-18), electrical current and nanoparticles $(19,20)$. 
The current research pursued to reveal the ability of radiation exposed protoscoleces to stimulate the production of WBCs, and the cellular acquired immunity represented by delayed- type hypersensitivity in mice infected with secondary hydatidosis.

\section{Materials and Methods}

\section{Experimental animals}

One month old experimental mice, animal house bred (in the Scientific Research, College of Education for Pure Sciences), worm free males of BALB/c mice were used

\section{Collect of hydatid cysts and estimation of protoscoleces Vitality}

Larval stages of E. granulosus were gained from livers of infected sheep slaughtered in Mosul city massacre. Protoscoleces were isolated from the larval stages, under disinfected conditions (21). Vitality was assessed (22). 2000 irradiated protoscoleces/mouse were inoculated into the peritoneal cavity of mice, treated group. 2000 not radiated protoscoleces/ mouse were injected into the peritoneal cavity of mice, control group, (23).

\section{Laser device}

The laser device, (ND / Y3AL5G12) 1000 milliwatt and a wavelength of $532 \mathrm{~nm}$ (2), was used (figure $1)$.

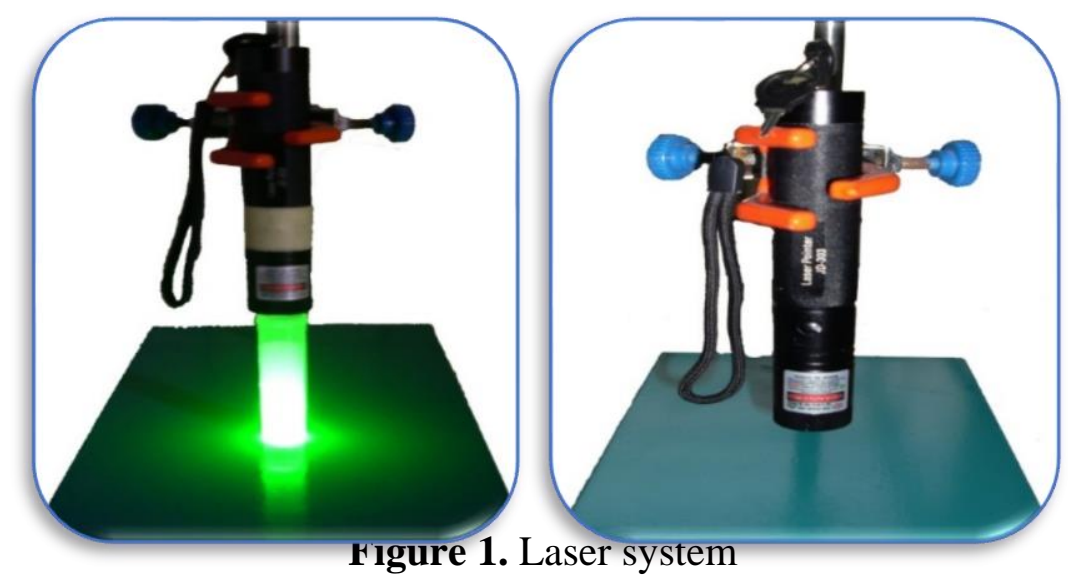


Journal of Education and Science (ISSN 1812-125X), Vol: 30, No: 3, 2021 (34-44)

Special Issue for Proceeding of $3^{\text {rd }}$ National (1 ${ }^{\text {st }}$ international conference of biology) (ICBSUM 2021) 5, 6 July

College of Education for Pure Science, University of Mosul, Mosul, Iraq.

\section{Treatment Schedule}

Six groups of mice were used, five for each group, animals of the 1st, 2nd, 3rd and 4th groups were injected intraperitoneally with 2000 protoscoleces exposed to laser radiation, with viability $70 \%, 57 \%$, $50 \%, 40 \%$, the fifth positive control group was injected intraperitoneally with unexposed protoscoleces with $100 \%$ viability (15). The sixth negative control group was neither injected with protoscoleces nor exposed to laser radiation.

\section{Blood}

The experimental animals of the five groups were anesthetized with Diethyl ether, blood was withdrawn from the ophthalmic venous plexus according to Waynforth (24), one, two, three months post infection, for total count of WBCs according to Dacie and Lewis (25).

\section{Delayed-type hypersensitivity}

\section{Elaboration of antigen and assessment of foot pad response}

Protoscoleces antigen was elaborated in accord with Dottorini et al. (26). Protein was assessed in accord with Schacterle and Pollack (27). Foot pad swelling to the antigen was measured (Ali-Khan 28). The antigen was injected into the right foot of the mouse at a concentration of 139 micrograms / ml after sterilizing the injection area with alcohol. The left foot was injected with the same volume of sterile PBS; the foot thickness was measured using the Vernier after 3, 24 and 48 hours of injection. The difference between the thickness of the left and right foot pad is a measure of hypersensitivity.

\section{Statistical analysis}

Results analyzed statistically by Complete Randomized Analysis CRD and by Duncan's Multiple Range Test to detect the significant differences between treated (mice injected with protoscoleces that exposed to laser radiation) and not treated positive and negative control groups (29).

\section{Results And Discussion}

Total White Blood Cells Count

Table (1) reveals alterations in the overall WBCs counting in mice injected with radiated protoscoleces in contrast with not exposed positive and negative mice for 1, 2, 3 months. A significant increase $(\mathrm{P}<0.01)$ in the total white blood cells count was observed in the treated mice, reported $13962 \mathrm{cell} / \mathrm{cm} 3$ after 120 minute of exposure, two months post infection, followed by $9837 \mathrm{cell} / \mathrm{cm} 3$ after 240 minute, three months post infection and 9010 cell/cm3 after 60 minutes, one month post infection, respectively, in comparison with the positive control group 5420, 6370 and 5350 cell/ $\mathrm{cm} 3$, respectively, which in turn showed a significant decrease $(\mathrm{P}<0.05)$ in the Total white blood cells count when compared to the negative control 6690, 7110 and 6850cell/cm3, respectively. 
Table 1. changes in total white blood cells count in mice injected with laser radiated protoscoleces in comparison with positive and negative control groups for 1, 2, 3 months

\begin{tabular}{cccc}
\hline $\begin{array}{c}\text { Exposure } \\
\text { period (min) } \\
\text { vitality }\end{array}$ & $\begin{array}{c}\text { Total count of leukocytes } \\
\text { cell / cm3 (1stmonth) }\end{array}$ & $\begin{array}{c}\text { Total count of leukocytes } \\
\text { cell / cm3 (2ndmonth) }\end{array}$ & $\begin{array}{c}\text { Total count of leukocytes } \\
\text { cell / cm3 (3rdmonth) }\end{array}$ \\
\cline { 2 - 4 } $40 / 70 \%$ & \pm SD mean & \pm SD mean & \pm SD mean \\
\hline & $8380 \mathrm{ab}$ & $8570 \mathrm{c} \mathrm{b}$ & $9012 \mathrm{ab}$ \\
$60 / 57 \%$ & \pm 1118.369 & \pm 903.188 & \pm 636.76 \\
& $9010 \mathrm{a}$ & $8760 \mathrm{~b}$ & $9562 \mathrm{ab}$ \\
$120 / 50 \%$ & \pm 810.401 & \pm 1346.013 & \pm 3236.00 \\
& $6450 \mathrm{c}$ & $13962 \mathrm{a}$ & $9475 \mathrm{ab}$ \\
$240 / 40 \%$ & \pm 1479.442 & \pm 5437.644 & \pm 1121.10 \\
& $6750 \mathrm{c}$ & $9650 \mathrm{~b}$ & $9837 \mathrm{a}$ \\
$\mathrm{C}+$ & \pm 882.468 & \pm 389.935 & \pm 790.86 \\
& $5350 \mathrm{c}$ & $5420 \mathrm{c}$ & $6370 \mathrm{c}$ \\
$\mathrm{C}-$ & \pm 1426.972 & \pm 590.127 & \pm 2050.18 \\
& $6850 \mathrm{bc}$ & $6690 \mathrm{c} \mathrm{b}$ & $7110 \mathrm{c} \mathrm{b}$ \\
\hline
\end{tabular}

\section{Delayed-type hypersensitivity}

Table (2) shows the changes in the rates of foot pad thickness in mice injected with irradiated protoscoleces, contrasted to the positive set for 1, 2,3month post infection. A significant increase $(\mathrm{P}<0.01)$ was observed in the rates of thickness in the treated mice reported a maximum thickness $2.94 \mathrm{~mm}$ followed by $2,86 \mathrm{~mm}$ and $2.64 \mathrm{~mm}$, after 120 minute exposure, 24 hours post antigen injection, two months, one month and three months post infection, respectively, compared to the positive control $1.18 \mathrm{~mm}, 1.80 \mathrm{~mm}$ and $1.72 \mathrm{~mm}$, after120 minute exposure, 24 hours post antigen injection, two months, one month and three months post infection, respectively.

Table 2. Changes in the foot pad thickness $(\mathrm{mm})$ in mice injected with laser radiated protoscoleces in comparison with positive and negative control groups for 1,2,3 months

\begin{tabular}{|c|c|c|c|c|c|c|c|c|c|}
\hline \multirow{2}{*}{$\begin{array}{l}\text { Exposure } \\
\text { period } \\
(\min ) / \\
\text { vitality }\end{array}$} & \multicolumn{3}{|c|}{$\begin{array}{c}\text { Foot pad } \\
\text { thickness(mm) } \\
\text { (1st month) }\end{array}$} & \multicolumn{3}{|c|}{$\begin{array}{c}\text { Foot pad } \\
\text { thickness(mm) } \\
\text { (2nd months) }\end{array}$} & \multicolumn{3}{|c|}{$\begin{array}{c}\text { Foot pad } \\
\text { thickness(mm) } \\
\text { (3rd months) }\end{array}$} \\
\hline & $\begin{array}{l}3 \mathrm{hr} . \\
\pm \mathrm{SD} \\
\text { mean }\end{array}$ & $\begin{array}{l}24 \mathrm{hr} . \\
\pm \mathrm{SD} \\
\text { mean }\end{array}$ & $\begin{array}{l}48 \mathrm{hr} . \\
\pm \mathrm{SD} \\
\text { mean }\end{array}$ & $\begin{array}{l}3 \mathrm{hr} . \\
\pm \mathrm{SD} \\
\text { mean }\end{array}$ & $\begin{array}{l}24 \mathrm{hr} . \\
\pm \mathrm{SD} \\
\text { mean }\end{array}$ & $\begin{array}{l}48 \mathrm{hr} . \\
\pm \mathrm{SD} \\
\text { mean }\end{array}$ & $\begin{array}{l}3 \mathrm{hr} . \\
\pm \mathrm{SD} \\
\text { mean }\end{array}$ & $\begin{array}{l}24 \mathrm{hr} . \\
\pm \mathrm{SD} \\
\text { mean }\end{array}$ & $\begin{array}{l}48 \mathrm{hr} . \\
\pm \mathrm{SD} \\
\text { mean }\end{array}$ \\
\hline $40 / 70 \%$ & $\begin{array}{l}1.94 \mathrm{a} \\
\pm 0.782\end{array}$ & $\begin{array}{l}2.16 \mathrm{ab} \\
\pm 0.461\end{array}$ & $\begin{array}{l}1.62 \mathrm{a} \\
\pm 0.334\end{array}$ & $\begin{array}{l}1.86 \mathrm{c} \mathrm{b} \\
\pm 0.403\end{array}$ & $\begin{array}{l}2.62 \mathrm{a} \\
\pm 0.334\end{array}$ & $\begin{array}{l}1.84 \mathrm{a} \\
\pm 0.350\end{array}$ & $\begin{array}{l}1.82 \mathrm{a} \\
\pm 0.449\end{array}$ & $\begin{array}{l}2.02 \mathrm{a} \\
\pm 0.723\end{array}$ & $\begin{array}{l}1.54 \mathrm{a} \\
\pm 0.296\end{array}$ \\
\hline $60 / 57 \%$ & $\begin{array}{l}1.82 \mathrm{a} \\
\pm 1.077\end{array}$ & $\begin{array}{l}2.54 \mathrm{ab} \\
\pm 0.433\end{array}$ & $\begin{array}{l}1.46 \mathrm{a} \\
\pm 0.698\end{array}$ & $\begin{array}{l}2.42 \mathrm{a} \\
\pm 0.286\end{array}$ & $\begin{array}{l}2.72 \mathrm{a} \\
\pm 0.618\end{array}$ & $\begin{array}{l}2.02 \mathrm{a} \\
\pm 0.438\end{array}$ & $\begin{array}{l}2.06 \mathrm{a} \\
\pm 0.240\end{array}$ & $\begin{array}{l}2.46 \mathrm{a} \\
\pm 0.466\end{array}$ & $\begin{array}{l}1.60 \mathrm{a} \\
\pm 0.644\end{array}$ \\
\hline $120 / 50 \%$ & $\begin{array}{l}2.14 \mathrm{a} \\
\pm 0.512\end{array}$ & $\begin{array}{l}2.86 \mathrm{a} \\
\pm 0.384\end{array}$ & $\begin{array}{l}1.74 \mathrm{a} \\
\pm 0.680\end{array}$ & $\begin{array}{l}2.22 \mathrm{ab} \\
\pm 0.402\end{array}$ & $\begin{array}{l}2.94 \mathrm{a} \\
\pm 0.541\end{array}$ & $\begin{array}{l}1.70 \mathrm{a} \\
\pm 0.463\end{array}$ & $\begin{array}{l}1.58 \mathrm{a} \\
\pm 1.089\end{array}$ & $\begin{array}{l}2.64 \mathrm{a} \\
\pm 0.606\end{array}$ & $\begin{array}{l}1.46 \mathrm{a} \\
\pm 0.826\end{array}$ \\
\hline $240 / 40 \%$ & $\begin{array}{l}1.52 \mathrm{a} \\
\pm 0.311\end{array}$ & $\begin{array}{l}1.94 \mathrm{~b} \\
\pm 0.531\end{array}$ & $\begin{array}{l}1.42 \mathrm{a} \\
\pm 0.414\end{array}$ & $\begin{array}{l}1.36 \mathrm{~cd} \\
\pm 0.320\end{array}$ & $\begin{array}{l}1.82 \mathrm{~b} \\
\pm 0.649\end{array}$ & $\begin{array}{l}1.54 \mathrm{a} \\
\pm 0.378\end{array}$ & $\begin{array}{l}1.74 \mathrm{a} \\
\pm 0.861\end{array}$ & $\begin{array}{l}2.38 \mathrm{a} \\
\pm 0.756\end{array}$ & $\begin{array}{l}1.28 \mathrm{a} \\
\pm 0.697\end{array}$ \\
\hline $\mathrm{C}+$ & $\begin{array}{l}1.46 \mathrm{a} \\
\pm 0.572\end{array}$ & $\begin{array}{l}1.80 \mathrm{~b} \\
\pm 0.994\end{array}$ & $\begin{array}{l}1.38 \mathrm{a} \\
\pm 0.521\end{array}$ & $\begin{array}{l}0.98 \mathrm{~d} \\
\pm 0.511\end{array}$ & $\begin{array}{l}1.18 \mathrm{~b} \\
\pm 0.708\end{array}$ & $\begin{array}{l}1.42 \mathrm{a} \\
\pm 0.471\end{array}$ & $\begin{array}{l}1.16 \mathrm{a} \\
\pm 0.409\end{array}$ & $\begin{array}{l}1.72 \mathrm{a} \\
\pm 0.715\end{array}$ & $\begin{array}{l}1.00 \mathrm{a} \\
\pm 0.244\end{array}$ \\
\hline
\end{tabular}




\section{Journal of Education and Science (ISSN 1812-125X), Vol: 30, No: 3, 2021 (34-44) \\ Special Issue for Proceeding of $3^{\text {rd }}$ National (1st international conference of biology) (ICBSUM 2021) 5, 6 July College of Education for Pure Science, University of Mosul, Mosul, Iraq.}

The outcome of the current research demonstrated a significant increase in the total count of WBCs in mice injected with radiated protoscoleces (table 1) Which leads to stimulating the immune system, as Al-Ghamdi et al. (30) stated that LLLT enhances rapid multiplication of different types of cells in the culture, including stem cells, which are the source of all white blood cells, and radiation therapy stimulates the production of high levels of Adenosine Tri Phosphate, Ribonucleic Acid and Deoxyribonucleic acid in stemmed cells and another types of cells. Consequently, treatment with this radiation improves cell reproduction without causing any toxic effects. The results of low-intensity irradiation also differ according to the intensity of the energy and the wavelengths to which target cells are exposed (30).

The study has shown that the energy density value that ranges between 0.4-0.5 joules / centimeter square and the visual spectrum extending from 600-700 nanometer of eradiation, were good enhancements for the reproduction of different cell types. This effect includes several mechanisms, one of which is that the laser power is absorbed by the intracellular chromophores and transformed into metabolic energy. Therefore, cellular Adenosine Triphosphate scales augment approximately twice next helium-neon eradiation (31). ATP works by the diverse P2 nucleotide receptor subtypes to rise calcium concentration within the cell (32-34). ATP simultaneously regulates protein construction, DNA construction, and gene expression $(33,35)$. One theory regarding the effect of LLLT states that the laser has the ability to affect photoreceptors in cells. This mechanism is called photobiology, or biostimulation, It has been provided in details that photobiostimulation happens by enzymes of the electron transfer chain in mitochondria, including higher rates of cell respiration, either via endogenous porphyrins in the cell or by cytochrome $\mathrm{C}$ (36), which increases cellular and functional metabolism. The bio stimulating influence of the low level laser therapy results in an augmentation in microcirculation, high levels of ATP production, RNA and DNA building, leading to improved cellular oxygenation, nutrition, and renovation, and enhancement of the electron transport system in the mitochondria.

Yu et al. (37) claimed that Photons enter the cell and are absorbed directly by chromophore carriers that are situated either in the mitochondria or the cell membrane. These color carriers interact powerfully with lasers. The energy of photons is transformed into chemical energy within a cell, in the shape of Adenosine Triphosphate, which improves cellular activities and cell reproduction rates. The ability to be permeated of the cell membrane changes, following by physiological alterations in the objective cells. The degree of bio stimulation of laser radiation relies on the wavelength at the same time the physiological status of the cell during the irradiation period (38).

The infected mice showed a decrease in the total white blood cell count because of the infiltration and migration of the cells to the sites of infection, where the parasite is present in order to control the growth the evolution of secondary hydatid cysts.

Concerning cell-mediated immunity, the current research exhibited a significant increase in an acquired cellular immune response represented by the delayed-type hypersensitivity test (table 2) in mice injected with irradiated protoscoleces, in contrast with the positive set. This increase may be attributed to the ability of laser irradiation to induce cellular immunity represented by swelling in the thickness of the pad that continued after 24 hours of antigen injection, by inducing division, reproduction, division and differentiation of immune cells $(39,40)$ boosting and modifying the immune system $(41)$. The increase in the thickness is also attributed to the effect of the laser on the differential activation of the antigen presenting cells, which include macrophage cells, dendritic cells, and B lymphocytes leading to the release of a number of pro inflammatory cytokines in the cells that attract and activate macrophages (42- 44), this result is consistent with Kivity et al. (45) in patients with Echinococcus cyst. The researchers also 
explained by the histological examination of the pad, that the growth is due to the infiltration of neutrophils, macrophages mononuclear and lymphocytes, and this infiltration, which is a characteristic of the typical late hypersensitivity reaction, continues to the seventh day, as it was observed on the sixth day of neutrophil cells and mononuclear cells by Ryu \& Kim (46). Czuprinski et al. (47) suggested that the immunized mice were able to recruit a large number of macrophage cells at the site of infection due to the release of lymphokine by lymphocytes signaling the role of cellular immunity.

The most characteristic feature of the hypersensitivity reactions is the accumulation of eosinophils in the tissues preceded by the process of accumulation of TH2 lymphocytes $(46,47)$. The Bacillus Chalmette Guerine (BCG) vaccine was used with the complete Frunze's adjuvant or with S. mansoni eggs in the delayed hypersensitivity test in mice, it was concluded that the delayed hypersensitivity reactions stimulated the production of attracting chemicals and binding molecules to endothelial cells necessary for eosinophilia migration, and the eosinophil migration process was inhibited by depleting TH 2 cells or the use of anti-INF-, which indicates the vital role played by TH2 cells and - $\gamma$ INF in delayed hypersensitivity reactions $(48,49)$, the increase in thickness of foot pad in the present study may also be attributed to laser stimulation of-INF and INF-alpha, TNF-alpha. Willey et al. (50) indicated that IL-2, INF-, and TNFdetachment of helper $\mathrm{T}$-Helper cells are responsible for delayed hypersensitivity reactions. Untreated infected mice showed a low depressed Cell-Mediated Immunity (CMI) response, and this is similar to what be observed by Khan (28) in mice infected with E. multilocularis, and in mice infected mice with E. granulosus (45).

\section{Conclusion}

It could be well concluded that laser irradiated protoscoleces of Echinococcus granulosus has a significant impact on the total count of WBCs by induction division and proliferation of the cells, and on cellmediated immunity, by stimulation of delayed-type hypersensitivity reactions in mice, This technique may well be used in the future as an alternative remedy against this disease.

\section{Acknowledgements}

The authors would like to Acknowledge University of Mosul, Education College for Pure Sciences for supporting the current research.

\section{References}

1.Dybicz M, Gierczak A, Dąbrowska J, Rdzanek L Michałowicz B. Molecular diagnosis of cystic echinococcosis in humans from central Poland. Parasitol. Int. 2013; 62: 364-367. DOI: 10.1016/j.parint.2013.03.005.

2.Zhang J, Ye B, Kong j, Cai H, Zhao Y, Han X, Li F. In vitro protoscolicidal effects of high-intensity focused ultrasound enhanced by a superabsorbent polymer. Parasitol. Res. 2013; 112: 385-391. DOI: $10.1007 / \mathrm{s} 00436-012-3176-3$.

3. Daş K Sozen S, Uzun AS, Menekşe E, Karateke F, Bali I. Spontaneous rupture of hydatid cyst due to strain-defecation. J. Acute. Dis. 2012; 1(2): 152-153. https://doi.org/10.1016/S2221-6189(13)600372. 
4. Eckert J, Thompson RCA. Historical Aspects of Echinococcosis. In Advances in Parasitology, 2017; Vol.(95). https://doi.org/10.1016/bs.apar.2016.07.003.

5. Lissandrin R, Tamarozzi F, Piccoli L, Tinelli C, De Silvestri A, Mariconti M, Brunetti E. Factors influencing the serological response in hepatic echinococcus granulosus infection. American Journal of Tropical Medicine and Hygiene, 2016; 94(1): 166-171. https://doi.org/10.4269/ajtmh.15-0219.

6. Díaz Á. Immunology of cystic echinococcosis (hydatid disease). British Medical Bulletin, 2017; 124(1): 121-133. https://doi.org/10.1093/bmb/ldx033.

7. Khanbabaie S, Riazi M, Chang $\mathrm{CH}$, Yunus $\mathrm{MH}$, Noordin R. Lateral flow dipstick antigen assay for human cystic echinococcosis. Acta Tropica, 2019;190: 171-176. https://doi.org/10.1016/j.actatropica.2018.11.018.

8.Thompson RCA, Jenkins DJ. Echinococcus as a Model System: Biology and Epidemiology. International Journal for Parasitology 2014; 44(12):865-77. DOI: 10.1016/j.ijpara.2014.07.005.

9. Díaz A, Casaravilla C, Barrios AA, Ferreira AM. Parasite molecules and host responses in cystic echinococcosis. Parasite Immunology. 2016; 38(3): 193-205. https://doi.org/10.1111/pim.12282.

10. Kern P, da Silva AM, Akhan O, Müllhaupt B, Vizcaychipi KA, Budke, C, Vuitton DA. The echinococcoses: diagnosis, clinical management and burden of disease. In Advances in parasitology 2017; Vol. (96): 259-369. Elsevier. DOI: 10.1016/bs.apar.2016.09.006

11. Cai H, Chen LL, Ye B, Liu AB, Zhang J, Zhao YF. The destructive effects of high-intensity focused ultrasoundon hydatid cysts enhanced by ultrasound contrast agent and super absorbent polymer alone or in combination. Parasitol. Res., 2013. 112:707-717. DOI: 10.1007/s00436-012-3191-4

12. Eslamirad Z, Soleimani H, Hajihossein R, Rafiei F. Evaluation of lethal effect of microwave exposure on protoscoleces of hydatid cyst in vitro. Asian Pacific Journal of Tropical Disease. 2015; 5(10): 821824. https://doi.org/10.1016/S2222-1808(15)60938-0.

13. Yuan Q, Li B, Jiang S, Zhao Q, Duo J, Huang X. Gamma-Ray treatment of echinococcus protoscoleces prior to implantation in mice reduces echinococcosis. BioMed research international, 2016; https://doi.org/10.1155/2016/9027489.

14. Uçar M, Akgül AK, Çelik F, Kılıç N. Excisional treatment of renal hydatid cyst mimicking renal tumor with diode laser technique: A case report. Journal of Pediatric Urology. 2016; 12(4): 264-e1. DOI: 10.1016/j.jpurol.2016.04.009.

15. Ali AA, Mohammed ZD. Effect of laser radiation on the immune response of mice against infection with secondary hydatid disease. I. Growth and development of hydatid cysts. Journal of Education and Science. 2018; 27(3): 66- 80. doi:10.33899/edusj.2018.159319

16. Çolak B, Aksoy F, Yavuz S, Demircili ME. Investigating the effect of gold nanoparticles on hydatid cyst protoscoleces under low-power green laser irradiation. Turkish journal of surgery, 2019; 35(4), 314. doi: 10.5578/turkjsurg.4354.

17. Mirabile E, Solomon N, Fields PJ, Macpherson CNL. Progress towards international adoption of the World Health Organization ultrasound classification of cystic echinococcosis. Acta Tropica, 2019; 189, 6-9. https://doi.org/10.1016/j.actatropica.2018.09.024 
18. Ramdan BB, Ali AA. Application of ultrasound contra infection with secondary hydatidosis in mice. Iraqi Journal of Veterinary Sciences 2020; 34(2), 397-403. Doi: 10.33899/ijvs.2019.126132.1240

19.Ali AA, Salim F. Effect of direct electrical current on protoscoleces of Echinococcus granulosus in vitro and on immune response of BALB/c mice against infection with secondary hydatid disease. The Eurasia Proceedings of Science, Technology, Engineering\& mathematics (EPSTEM) 2018; 3:90-102.

20. Albalawi AE, Alanazi AD, Baharvand P, Sepahvand M, Mahmoudvand H. High Potency of Organic and Inorganic Nanoparticles to Treat Cystic Echinococcosis: An Evidence-Based Review. Nanomaterials, 2020; 10(12), 2538. DOI: 10.3390/nano10122538.

21. Smyth JD. In vitro culture of Echinococcus spp. Proc. 13th ed., Int. Cong. Hydit. Madrid, 1985; pp 84-95. https://doi.org/10.1016/0020-7519(74)90028-9

22.Smyth JD, Barrett NJ. Procedure for testing the viability of human hydatid cysts following surgical removal especially after chemotherapy. Trans. Roy. Soc. Trop. Med. Hyg. 1980; 74: 649-652. DOI: 10.1016/0035-9203(80)90157-1

23. Wangoo A, Ganguly NK, Mahgjan RC. Phagocytic activity of monocytes in murine model of Echinococcus granulosus of human origin. J. Med. Res., 1989; 89: 40-42.

24. Waynforth HB. Experimental and Surgical Technique in the Rat. Academic Press Inc., (London) LTD, NWI, 1980; 29.

25. Dacie JV, Lewis JB. Parasitical Hematology. 6th ed., Churchill Livingstone Publication U.K., 1986; pp 22-49.

26. Dottorini S, Sparvoli M, Bellucci C, Magnini M. Echinococcus granulosus: diagnosis of hydatid disease in man. Annals of Tropical Medicine \& Parasitology, 1985; 79(1), 43-49. https://doi.org/10.1080/00034983.1985.11811887

27. Schacterle GR, Pollack RLA. simplified method for the quantitative assay of small amount of protein in biologic material. Anal. Biochem., 1973; 51: 654-655. DOI: 10.1016/0003-2697(73)90523-X

28.Ali-Khan Z. Echinococcus multilocularis: Cell-mediated immune response in early and chronic alveolar murine hydatidosis. Experimental Parasitology. 1978; 46(2), 157-165. https://doi.org/10.1016/0014-4894(78)90128-5

29. Al-Zubaidy KMD, Al-Falahy MAH. Principles and Procedures. Statistics and Experimental Designs. 2016; Duhok University Press.

30. Al-Ghamdi KM, Kumar A, Moussa NA. Low-level laser therapy: A useful technique for enhancing the proliferation of various cultured cells. Laser Med. Sci., 2011; 27(1):237-249. DOI: $10.1007 / \mathrm{s} 10103-011-0885-2$

31. Karu T Pyatibrat, L. and Kalendo, G. Irradiation with He-Ne laser increases ATP level in cells cultivated in vitro. J. Photochem. Photobiol., 1995, B 27:219-223. https://doi.org/10.1016/10111344(94)07078-3.

32. Corr L, Burnstock G. Analysis of P2-purinoceptor subtypes on the smooth muscle and endothelium of rabbit coronary artery. J. Cardio. Pharmacol., 1994; 23:709-715. DOI: 10.1097/00005344- 
Journal of Education and Science (ISSN 1812-125X), Vol: 30, No: 3, 2021 (34-44)

Special Issue for Proceeding of $3^{\text {rd }}$ National (1 ${ }^{\text {st }}$ international conference of biology) (ICBSUM 2021) 5, 6 July

College of Education for Pure Science, University of Mosul, Mosul, Iraq.

199405000-00004

33. Kitajima S, Ozaki H, Karaki H. Role of different subtypes of P2 purinoceptor on cytosolic Ca2+ levels in rat aortic smooth muscle. Eur. J. Pharmacol ., 1994; 266:263-267. DOI: 10.1016/09224106(94)90135-X

34. Kalthof B, Bechem M, Flocke K, Pott L, Schramm M. Kinetics of ATP-induced Ca21 transients in cultured pig aortic smooth muscle cells depend on ATP concentration and stored Ca2+. J. Physiol ., 1996; 466:245-262. PMCID: PMC1175477

35. Malam-Souley R, Seye C, Gadeau AP. Nucleotide receptor P2u partially mediates ATP-induced cell cycle progression of aortic smooth muscle cells. J. Cell Physiol., 1996; 166:57-65 DOI: 10.1002/(SICI)1097-4652(199601)166:1.

36. Lubart R, Wollman Y, Friedmann H, Rochkind S, Laulicht I. Effects of visible and near-infrared lasers on cell cultures. Journal of Photochemistry and Photobiology B: Biology, 1992; 12(3), 305-310. https://doi.org/10.1016/1011-1344(92)85032-P.

37. Yu W, Naim JO, McGowan M, Ippolito K, Lanzafame RJ. Photomodulation of oxidative metabolism and electron chain enzymes in rat liver mitochondria. Photochem. Photobiol ., 1997; 66:866-871. DOI: 10.1111/j.1751-1097.1997.tb03239.x

38. Pinheiro AL, Carneiro NS, Vieira AL. Effects of low level laser therapy on malignant cells: In vitro study. J. Clin. Laser Med. Surg., 2002; 20:23-26. DOI: 10.1089/104454702753474977

39. Ohshiro T, Calderhead RG. Low-Level Laser Therapy: A practical Introduction. Wiley, New York, 1988; pp 17, 28-30, 33, 34. https://doi.org/10.1002/bjs.1800760445.

40. Huang YY, Chen ACH, Carroll J D, Hamblin MR. Biphasic dose response in low-level light therapy. Dose Response, 2009; 7:358-383.doi: 10.2203/dose-response.09-027.Hamblin

41. Luger EL, Rochkind S, Wollman Y, Kogan G, Dekel S. Effect of low-power laser irradiation on the mechanical properties of bone fracture healing in rats. Lasers Surg. Med., 1998; 22:97-102. doi: 10.1002/(sici)1096-9101(1998)22:2.

42. Abul Abbas K, Lichtman AH, Pillai S. Cellular and Molecular Immunology. 2014; 8th. ed. Elsevier Sanders. Philadelphia. U.S.A.

43. Male D, Brostoff J, Roth D, Roitt I. Immunology. 2012; 8th ed. Inter. Edith Mosby Elsevier ltd. U.K.

44. Yu HS, Chang KL, Yu CL, Chen JW, Chen GS. Low-energy helium-neon laser irradiation stimulates interleukin-1 alpha and interleukin-8 release from cultured human keratinocytes. J. Invest. Dermatol., 1996; 107:593-596. DOI: 10.1111/1523-1747.ep12583090

45. Kivity S, Heno N, Greif Z, Fireman E, Topilsky N. Diagnostic value of late cutaneous response to Casoni test in patients operated for Echinococcus cyst. Ann. Aller., 1993; 71(3): 247-250. PMID: 8372998

46. Ryu H, Kim C. Immunologic reactivity of a lipopoly saccharide-protein complex of type A Pasteurlla multocida in mice. J. Vet. Sci., 2000; 1 (2): 87-95. PMID: 14614303

47. Czuprinski CJ, Henson PE, Campell PA. Killing of Listeria monocystogenes by inflammatory 
neutrophils and mononuclear phagocytes from immune and non- immune mice. J. Leukocyte Biol., 1984; 35:193-208. https://doi.org/10.1002/jlb.35.2.193

48. Biedermann T, Kneilling M, Mailhammer R, Maier K, Sander CA, Kollias G, Kunkel SL, Hultner L, Rocken M. Mast cells control neutrophil recruitment during $\mathrm{T}$ cell-mediated delayed-type hypersensitivity reactions through tumor necrosis factor and macrophage inflammatory protein-2. J. Exp. Med., 2000; 192: 1441-1452. DOI: 10.1084/jem.192.10.1441

49. Teixeira MM, Talvani A, Tafuri WL, Lukacs NW, Hellewell PG. Eosinophil recruitment into sites of delayed-type hypersensitivity reactions in mice. J. Leukoc. Biol., 2001; 69: 353-360. PMID: 11261781

50. Willey JM, Sherwood LM, Woolverton CJ. Prescott Harley and Klein's Microbiology. 2008; 7th ed., McGraw-Hill Companies, Inc., U.S.A., pp 782-788. 